\title{
ЕЛЕКТРОННИЙ ПІДРУЧНИК ІЗ ДЕТАЛЕЙ МАШИН ТА КОНТРОЛЬ ЗНАНЬ СТУДЕНТІВ ЗА ДОПОМОГОЮ КОМП'ЮТЕРА
}

Антоненко I. I. Електронний підручник із деталей машин та контроль знань студентів за допомогою комп'ютера.

Розкрито особливості розроблення та використання електронного підручника з деталей машин $і$ системи контролю знань студентів ВПНЗ за допомогою компютера в умовах кредитно-модульної системи.

Ключові слова: деталі машин, електронний підручник, комп 'ютерне тестування.

Антоненко И. И. Электронный учебник по деталям машин и контроль знаний студентов при помощи компьютера.

Раскрыты особенности разработки и использования электронного учебника из деталей машин и системы контроля знаний студентов педвузов с помощью компьютера в условиях кредитно-модульной системы.

Ключевые слова: детали машин, электронный учебник, компьютерное тестирование.

Antonenko I. Electronic textbook of machine parts and control of students' knowledge using a computer.

The brought features over of development and use of electronic textbook from the details of machines and checking of knowledge of students of pedagogical institution of higher education system by means of computer in the conditions of the credit-module system.

Key words: details of machines, electronic textbook, computer testing.

Постановка проблеми. Ідея застосування комп’ютера в навчальному процесі виникла в межах концепції програмного навчання. Комп'ютерні технології завдяки можливостям зручної подачі навчальної інформацію перемагають кіно, телебачення, плакати та інші дидактичні засоби навчання. Сучасна педагогічна наука накопила чималий досвід використання інформаційних технологій у системи освіти.

Використання комп'ютера дозволяє суттєво скоротити час засвоєння навчального матеріалу. Найбільшою перевагою комп'ютерного навчання $\epsilon$ його адаптивність до потреб конкретного студента [1]. Активізуючи пізнавальну діяльність, комп'ютер забезпечує творчу діяльність під час самостійній роботі студентів.

В умовах Свропейської інтеграції необхідно моделювати методи контролю знань відповідно до Свропейської кредитно-трансферній системи (ECTS). Треба так вистроїти систему контроля знань студентів, щоб вона мала усі позитивні якості індивідуального навчання та водночас була масовою і не вимагала збільшення кількості викладачів.

Сучасна кредитно-модульна система грунтується на тестовому засобі організації контролю знань студентів. Використання комп'ютера у процесі тестування дозволяє забезпечити об'єктивність отриманих результатів та значно полегшити роботу викладачів за рахунок автоматизації процесу контроля знань. 
Тому основним напрямком модернізації системи освіти вищої школи $є$ створення і використання інформаційних засобів навчання, які дозволяють у відповідності із європейськими стандартами поєднати традиційну методику навчання з широкими дидактичними можливостями комп'ютерних технологій.

Мета статті: розроблення електронного підручника з деталей машин та системи контролю знань студентів в умовах кредитно-модульної системи навчання.

Процес створення навчальних підручників в електронній формі має здійснюватися згідно з дотриманням низки вимог, а саме:

1. Комплексність реалізації мети навчання традиційними й електронними засобами.

2. Відповідність електронного підручника віковим i розумовим особливостям розвитку учнів.

3. Повнота та якість представлення навчального матеріалу.

4. Контрольованість студентом і викладачем якості засвоєння навчального матеріалу[2].

Для підтримки вивчення дисципліни «Деталі машин» відповідно до навчальної програми для вищих педагогічних закладів освіти нами розроблено електронний підручник. Під час розроблення електронного підручника ми, передовсім, керувалися принципом доступності знань. Тому обрали програму найпростішу у використанні, а саме «Microsoft Word», що дозволяє користуватись інформацією навіть тим студентам, які слабко підготувались до роботи з комп'ютерною технікою, а також відтворити будь-який фрагмент на папері. Зручний автозміст програми «Microsoft Word» дозволяє швидко перейти до потрібної теми.

Створений електронний підручник містить навчальний матеріал iз деталей машин, підйомно-транспортних машин, а також має розділи зі взаємозамінності та стандартизації.

Після запуску електронного підручника на екрані комп'ютера 3'являється «Зміст» (див. рис. 1), в якому міститься посилання на всі розділи, активування яких здійснюється натисканням кнопки миші.

Використання електронного підручника під час вивчення дисципліни «Деталі машин» дозволяє швидко отримати необхідну навчальну інформацію.

Аналізуючи комп'ютерні контролюючі програми, ми намагалися знайти 3-поміж них таку, що при мінімальній вартості й мінімальному розмірі дискового простору у постійній пам'яті комп'ютера, забезпечувала б максимальну функціональність, широту налаштувань режимів роботи, простоту користування і створення тестів.

Комп’ютерна програма «Конструктор тестів» від компанії Keepsoft (автор П. Козловський) має такі можливості: використання необмеженого числа тем, питання можуть містити зображення, можливість ставити питання в довільному порядку з обмеженням відповіді за часом, шкалу оцінок можна налаштувати від 5-бальної до 100-бальної системи. Водночас вона має такі недоліки: великий розмір програми на установочному диску (317 Мб), програма потребує установки на комп'ютер і не може бути скопійованою з одного комп'ютера на інший, програмою не можна користуватися безкоштовно(ціна ліцензії 150\$). 
1.ОСНОВНІ ВІДОМОСТІ ПРО ДЕТАЛІ МАШИН ЗМІСТ

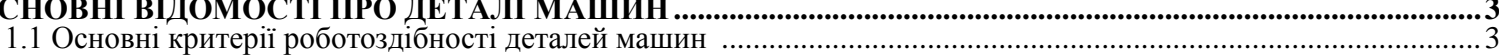

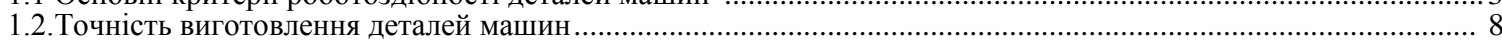

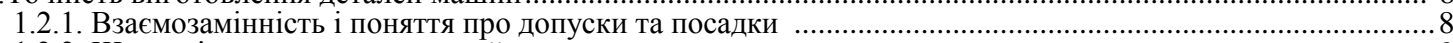

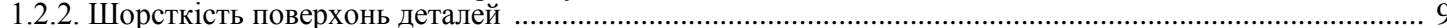

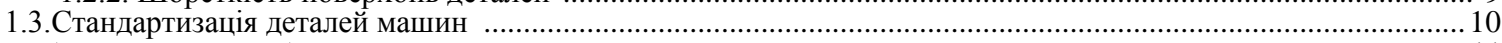

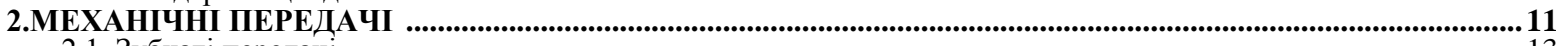

2.1. Зубчаті передачі

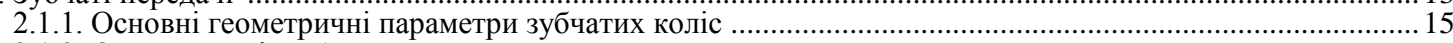

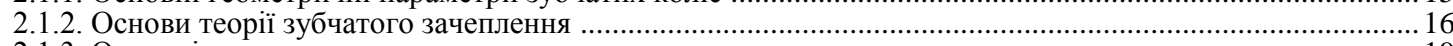

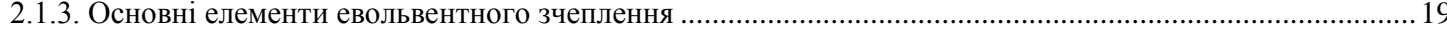

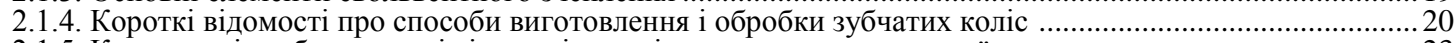

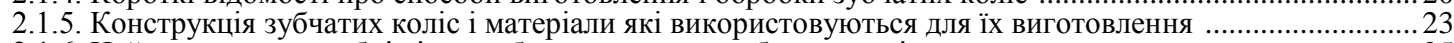

2.1.6. Найменше число зубців і способи коригування зубчатих коліс ....................................................25

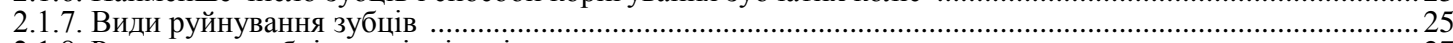

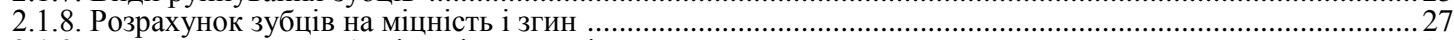

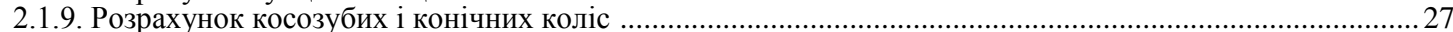

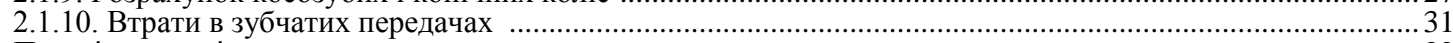

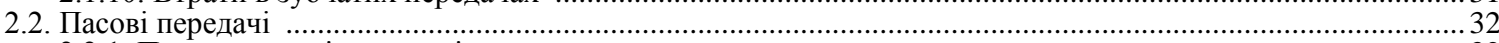

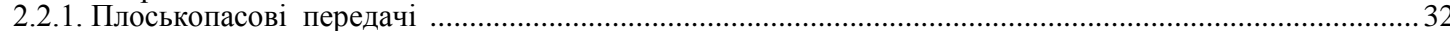

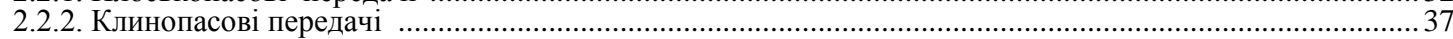

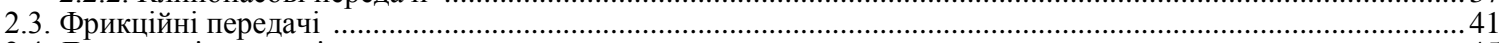

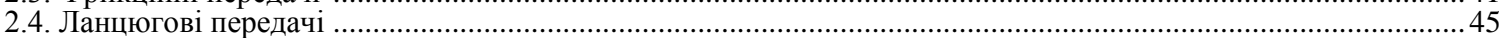

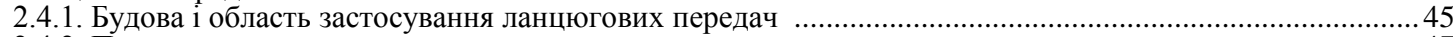

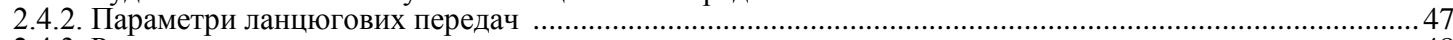

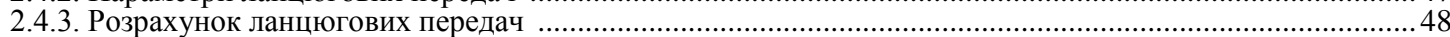

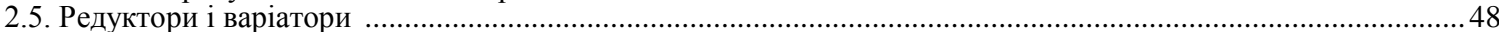

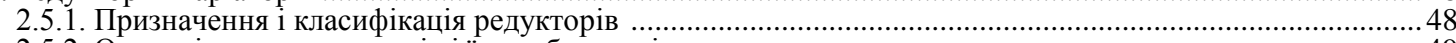

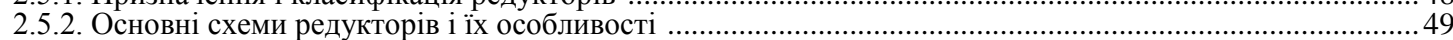

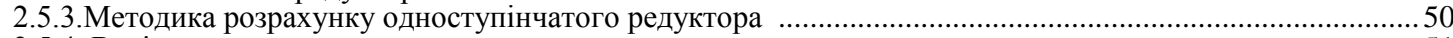

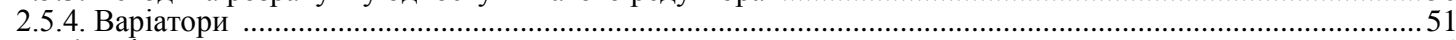

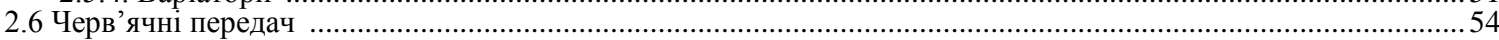

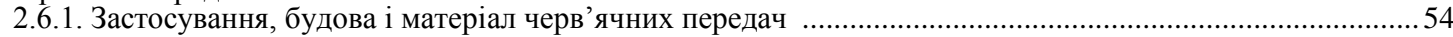

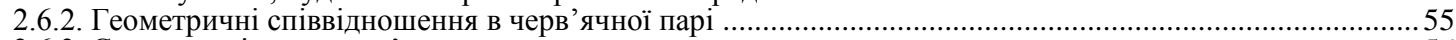

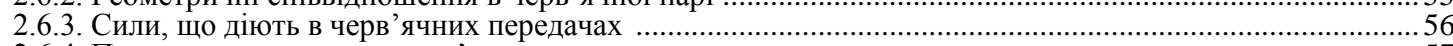

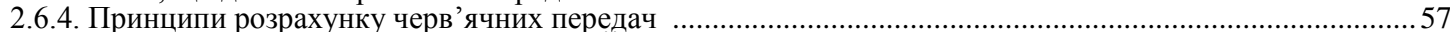

3. ОСНОВНІ ДЕТАЛІ ТА З'СДНАННЯ ДЕТАЛЕЙ МАШИН ........................................................................59

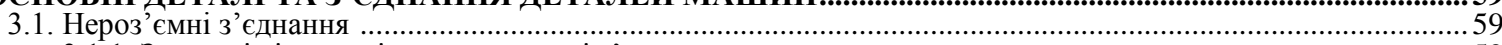

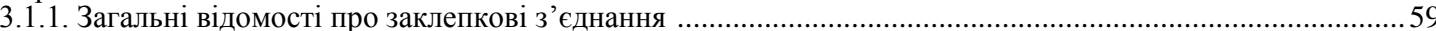

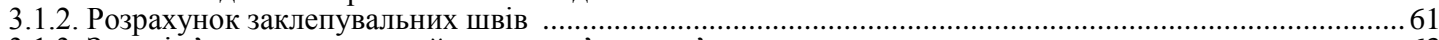

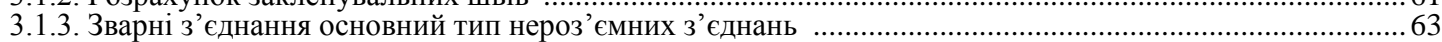

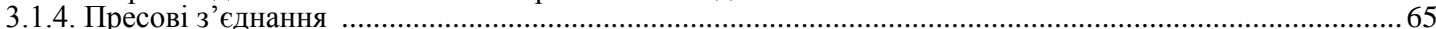

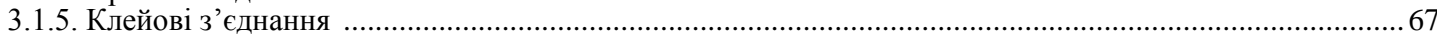

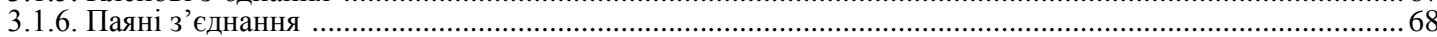

3.2. Роз'ємні з'єднання ............68

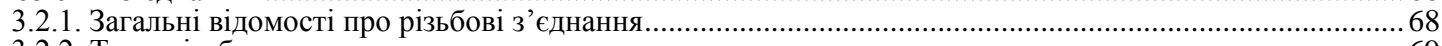

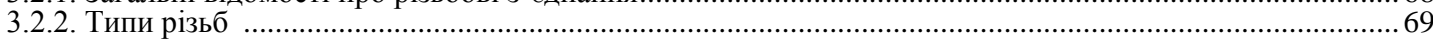

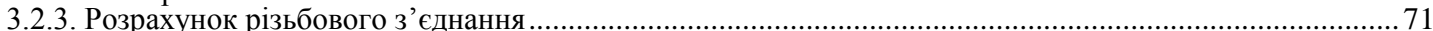

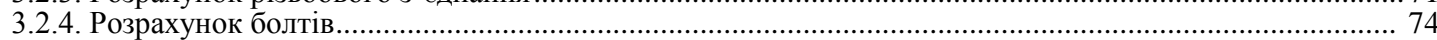

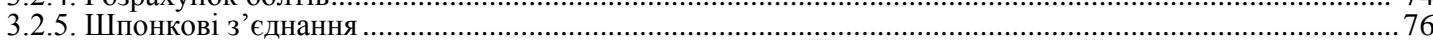

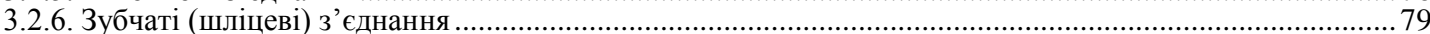

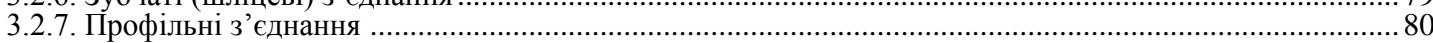

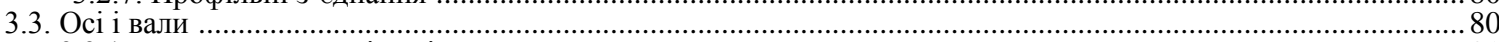

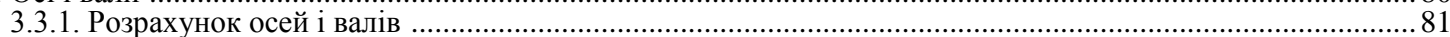

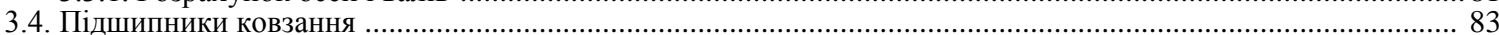

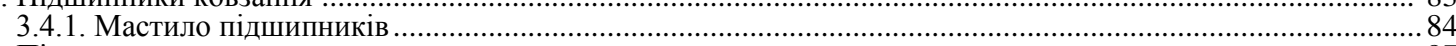

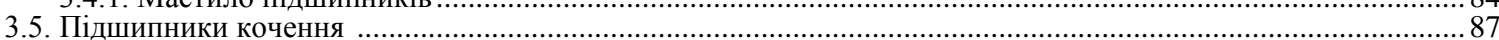

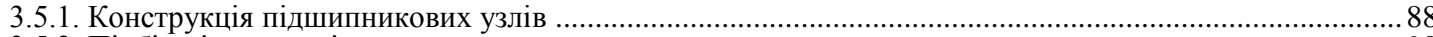

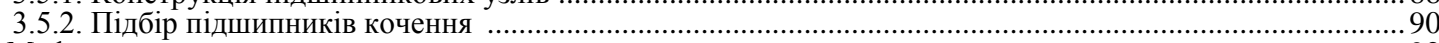

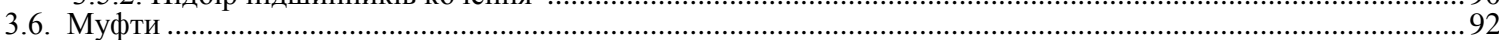

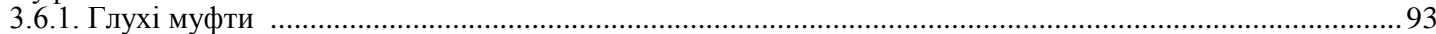

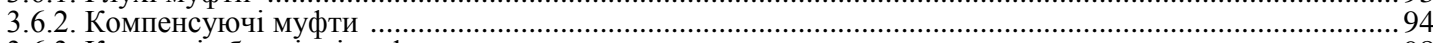

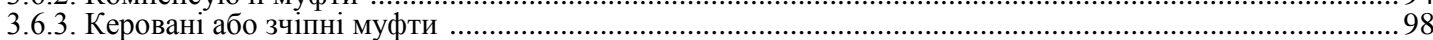

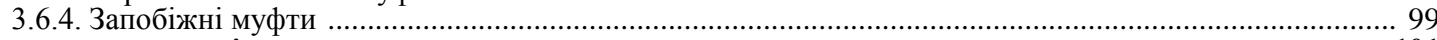

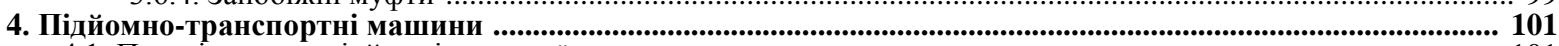

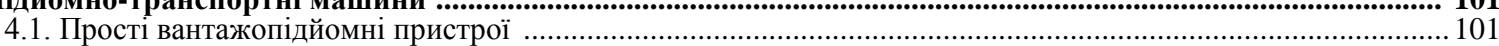

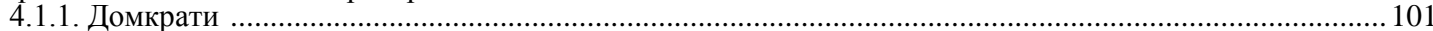

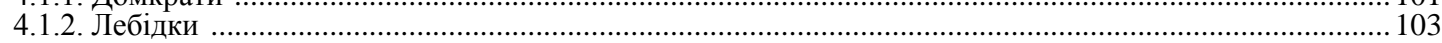

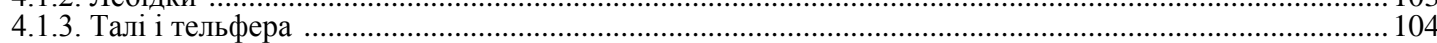

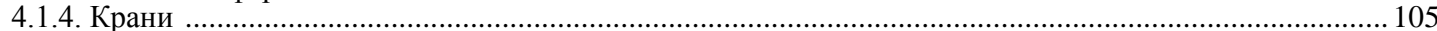

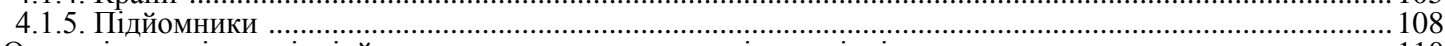

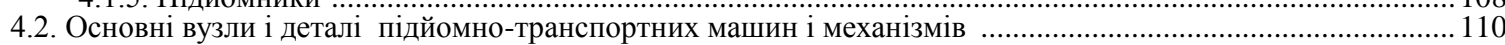

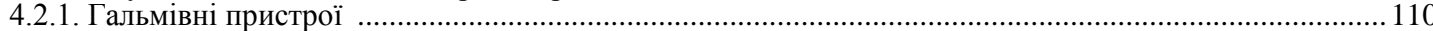

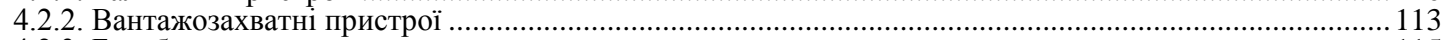

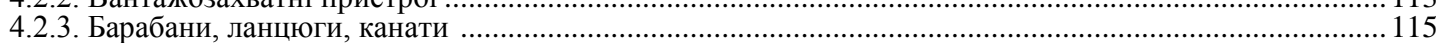

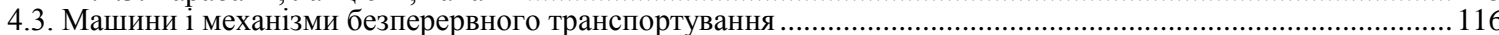

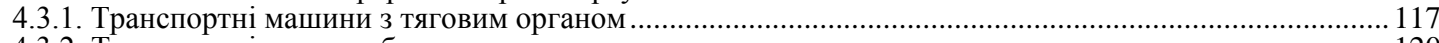

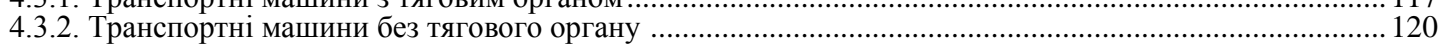

\section{Рис. 1 Зміст електронного підручника}


Значно зручніше контролювати знання студентів за допомогою програми «Assist 2» (Асистент 2). Під час запуску програми викладач може задавати питання у випадковому порядку з обмеженням часу відповіді. Вона має багато переваг: надзвичайно малий розмір на диску $(0,5$ Мб), легко копіюється 3 одного комп'ютера на інший, має широке коло налаштувань і зручний інтерфейс, підтримує використання малюнків. Під час експериментального дослідження ця програма працювала стабільно і надійно.

Отже, спираючись на результати аналізу параметрів роботи контролюючих програм, можна рекомендувати для контролю знань студентів під час вивчення технічних дисциплін програму Асистент2.

Визначаючи критерії оцінювання знань студентів, викладачі керуються на екзаменах національною 4-бальною шкалою (відмінно, добре, задовільно, незадовільно), а на заліках - 2-бальною шкалою(зараховано, не зараховано). Національна оцінка в умовах кредитно-модульної системи навчання підлягає обов'язковому переведенню до 100-бальної шкали ECTS, яка має 7 оцінок: A, B, C, D, E, FX, F. В умовах комп'ютерного тестування необхідно визначитися з оцінкою знань студентів у відсотках або балах.

За результатами педагогічної практики ВНЗ України і Росії можна рекомендувати необхідну кількість балів для переводу до оцінки ECTS, (див. табл.1).

Таблиия 1

\section{Оцінювання знань студентів}

в умовах кредитно-модульної системи навчання

\begin{tabular}{|c|c|c|c|}
\hline \multicolumn{2}{|c|}{ 3 національною шкалою } & \multirow{2}{*}{$\begin{array}{c}\text { За шкалою } \\
\text { ЕСТS }\end{array}$} & $\begin{array}{c}\text { Кількість } \\
\text { балік }\end{array}$ \\
\hline \multirow{5}{*}{ зарахов }
\end{tabular}

Для використання рекомендованої шкали оцінок за системою ECTS необхідно під час тестування пропонувати 10 питань. Тоді для оцінки «А» необхідно дати 10 правильних відповідей, оцінки « В » -9, оцінки « $\mathrm{C} »-8$, оцінки «D »-7, оцінки « $\mathrm{E} »-6$, оцінки « $\mathrm{FX} »-4-5$ правильних відповідей $\mathrm{i}$ « $\mathrm{F} »-0-3$ правильних відповідей.

Наявне розв'язання проблеми правдоподібності неправильних варіантів відповідей. Варіанти відповідей повинні бути правдоподібними зовнішньо і за змістом. Тож, найбільш доцільною структурою під час побудови тестів потрібно вважати один варіант правильний, три невірні, за наявності варіанта «правильної відповіді немає». Використання варіанту 
«правильної відповіді немає» дозволяє значно ускладнити відгадування студентами правильних відповідей. Контролююча програма «Асистент 2» дає змогу об'єктивно оцінити рівень знань студентів як на екзамені, так і при самоконтролі. У випадку «прогалин» у знаннях студент звертається до навчального електронного підручника.

Висновки. Комп'ютерізація вивчення дисципліни «Деталі машин» дозволяє активно залучати студентів до навчального процесу, а також надає можливість зручного автоматизованого тестування в умовах кредитномодульної системи навчання.

\section{Література}

1. Завізена Н. Комп'ютерізація освіти з позиції психолого-педагогічного аспекту / Н. Завзена // Рідна школа, 1999. - №11. - С. 62.

2. Бугайов О. І. Концептуальні положення щодо розробки педагогічних програмних засобів із фізики / О. І. Бугайов // Комп’ютер у школі та сім’ї. - 2004. - №8. - С. 13-16.

Стаття надійшла до редакції 12.04.2012 р.

УДК $378.14+373.31$

I. В. Казанжи, кандидат пед. наук, доцент, Миколаївський національний університет імені В. О. Сухомлинського

\section{КОМПЕТЕНТНІСНИЙ ПІДХІД У ФАХОВІЙ ПІДГОТОВЦІ МАЙБУТНІХ УЧИТЕЛІВ ПОЧАТКОВИХ КЛАСІВ}

Казанжи I. В. Компетентнісний підхід у фаховій підготовиі майбутніх учителів початкових класів.

У статті йдеться про значення компетентнісного підходу у процесі підготовки майбутніх фахівців в умовах євроінтеграџійних прочесів; розкрито складові професійно-виховної компетениії учителів початкової школи.

Ключові слова: євроінтеграція, компетентнісний підхід, професійно-виховна компетентність, готовність до виховної роботи.

Казанжи И. В. Компетентносный подход в профессиональной подготовке будущих учителей начальных классов.

В статье раскрывается значение компетентносного подхода в прочессе подготовки будущих специалистов в условиях евроинтегращионных процессов; раскрыты составляющие профессионально-воспитательной компетентности учителей начальной школь.

Ключевые слова: евроинтергащия, компетентносный подход, профессиональновоспитательная компетентность, готовность к воспитательной работе.

Kazanghy I. The competent approach in the professional training of future elementary school teachers.

The article is devoted to the meaning of a competent approach in the future specialists' training under the conditions of Euro Integration process; the components of school teachers' professional educative competence are described here.

Key words: Euro Integration, competent approach, educative competence, readiness to the educational work.

Постановка проблеми. У реалізації вимог із запровадження «європейського змісту» освіти та програми дій щодо положень Болонської декларації в систему вищої освіти і науки України пріоритетного значення набуває втілення у вітчизняній освітній процес вищих навчальних закладів 